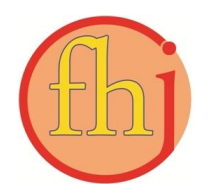

Faletehan Health Journal, 6 (3) (2019) 99-105

www. journal.Ippm-stikesfa.ac.id/ojs/index.php/FHJ

ISSN 2088-673X | e-ISSN 2597-8667

\title{
Pengaruh M otivasi Terhadap Pemberian Susu Formula Pada Bayi Berat Lahir Rendah
}

\author{
Rany Yulianie ${ }^{1 *}$ \\ ${ }^{1}$ Akademi Keperawatan Bidara Mukti Garut \\ *Corresponding Author: yulianiechandra@gmail.com
}

\begin{abstract}
Abstrak
ASI Eksklusif merupakan pemberian ASI saja termasuk kolostrum tanpa tambahan apapun. Pemberian ASI secara eksklusif selama 6 bulan merupakan intervensi kesehatan yang berdampak positif untuk menurunkan AKB. Tujuan penelitian ini untuk mengetahui pengaruh pengetahuan, dukungan sosial, sikap dan motivasi ibu terhadap pemberian susu formula pada Bayi Berat Lahir Rendah (BBLR). Penelitian ini menggunakan metode kuantitatif dengan desain cross sectional. Respondennya adalah ibu yang memiliki BBLR dan memberikan susu formula di Wilayah Kerja Puskesmas Karangpawitan dengan teknik total sampling sebanyak 80 orang, pengumpulan data menggunakan kuisioner. Teknik analisis menggunakan metode Structural Equation Modelling (SEM). Hasil penelitian menunjukkan motivasi memiliki pengaruh signifikan dengan pengaruh langsung (40,10\%) dan tidak langsung (0,27\%). M aka disimpulkan bahwa motivasi sangat berpengaruh terhadap pemberian susu formula pada BBLR. Untuk peningkatan motivasi perlu kerjasama antara ibu, suami dan petugas kesehatan dengan memberikan stimulasi positif tentang ASI agar produksi ASI tidak terhambat serta melakukan penyuluhan tentang ASI.
\end{abstract}

Kata Kunci: Bayi Berat Lahir Rendah, M otivasi, Susu formula

\begin{abstract}
Exclusive breastfeeding is breastfeeding only including colostrum without any additional. Exclusive breastfeeding for 6 months is a health intervention that has positive impact on reducing IMR. The purpose this study was to determine the effect of knowledge, social support, attitudes and motivation of mothers on formula feeding in Low Birth Weight. This research uses quantitative methods with cross sectional design. The respondents are mothers who have LBW and give formula milk in the working area of Karangpawitan Puskesmas with a total sampling technique of 80 people, collecting data using questionnaires. Analysis technique uses Structural Equation M odeling. The results showed motivation had a significant effect with direct (40.10\%) and indirect (0.27\%). It was concluded that motivation very influential on formula feeding at LBW. To increase motivation, collaboration between wife, husbands and health workers requires positive stimulation about breast milk so that milk production isn't hampered and counseling about breast milk.
\end{abstract}

Keywords: Formula M ilk, Low Birth Weight, Motivation 


\section{Pendahuluan}

ASI eksklusif yaitu bayi tidak diberikan makanan lain selain ASI selama 6 bulan dan pemberian ASI sebaiknya dilanjutkan hingga anak berusia 2 tahun dengan makanan pendamping ASI (Lilis Banowati, 2016). Pedoman Internasional yang menganjurkan pemberian ASI eksklusif selama 6 bulan pertama didasarkan pada bukti ilmiah tentang manfaat ASI bagi daya tahan hidup, pertumbuhan dan perkembangan bayi. Pemberian ASI eksklusif dapat mengurangi tingkat kematian bayi yang disebabkan penyakit yang umum menimpa saat usia bayi dan pemberian cairan selain ASI dapat meningkatkan risiko terkena penyakit. Pemberian ASI ekslusif dapat menurunkan angka kematian 30.000 bayi pertahun, terlebih diberikan pada bayi dengan BBLR (Nurheti Yuliarti, 2017).

BBLR di Indonesia mencapai 6,2\% dan Jawa Barat lebih dari itu yakni sebesar 6,7\%. Target Indonesia dalam pemberian ASI eksklusif baru mencapai $37,3 \%$ artinya masih ada $62,7 \%$ bayi yang masih belum mendapatkan ASI eksklusif padahal WHO menargetkan minimal 50\% dari penduduk suatu negara mendapatkan ASI eksklusif sedangkan Jawa Barat masih dibawah target yaitu $36,8 \%$ yang mendapatkan ASI eksklusif (Riskesdas, 2018).

ASI merupakan pilihan utama yang memiliki keuntungan seperti kadar protein tinggi, laktalbumin, zat kekebalan tubuh, lipase dan asam lemak esensial, laktosa, dan oligosakarida, juga memberikan perlindungan terhadap penyakit terutama BBLR. Pada tahun 2010 Garut mengalami BBLR sebanyak 201 bayi dan salah satu daerah dengan kasus BBLR yang tinggi adalah Karangpawitan dengan kasus sebanyak 82 bayi (Dinkes Garut, 2010). Berdasarkan survey pendahuluan yang dilakukan pada 10 orang ibu yang memiliki BBLR dan memberikan susu formula, sebanyak 5 orang ibu BBLR tidak memberikan ASI karena tidak tahu manfaat dari ASI, sebanyak 3 orang ibu BBLR tidak memberikan ASI karena bayinya rewel dan sebanyak 2 orang ibu BBLR tidak memberikan ASI karena keluarga lebih percaya pada susu formula. Berdasarkan latar belakang masalah diatas maka tujuan penelitian ini adalah untuk mengetahui pengaruh pengetahuan, dukungan sosial, sikap dan motivasi ibu terhadap perilaku pemberian susu formula oleh ibu pada BBLR.

\section{Metode Penelitian}

Penelitian ini adalah kuantitatif dengan menggunakan desain cross-sectional. Pengumpulan data yang digunakan dalam penelitian ini menggunakan kuisioner, dan langsung bertatap muka dengan responden agar dapat tergali informasi dari pertanyaan yang diajukan pada kuisioner. Pengambilan jumlah responden sesuai dengan kaidah jumlah sampel pada pedoman PLS (Partial Least Squares), dimana besaran sampel yang diambil adalah 5 hingga 10 kelipatan dari jumlah indikator yang akan diteliti maka besaran sampel pada penelitian ini kisaran 75 hingga 150 (Sugiono, 2009). Pada penelitian ini sampel sebanyak 80 responden dengan kriteria inklusi yaitu ibu yang memiliki bayi dengan BBLR usia 0-11 bulan yang masuk ke dalam wilayah kerja Puskesmas Karangpawitan dan diberikan susu formula. Penelitian dilakukan pada tanggal 5-10 November 2016 di wilayah kerja Puskesmas Karangpawitan. Teknik analisis menggunakan pendekatan kuantitatif dengan analisis menggunakan Structural Equation Modelling (SEM), penggunaan alat analisis ini dikarenakan adanya beberapa hubungan yang komplek dari beberapa variabel yang diuji dalam penelitian ini. Penggunaan SEM dapat memperluas kemampuan untuk menjelaskan dan adanya efisiensi statistik sebagai model yang menguji dengan metode menyeluruh tunggal.

\section{Hasil dan Pembahasan}

Berdasarkan hasil penelitian, diperoleh data hasil pengukuran inner model dan outer model seperti pada gambar 1 dan gambar 2. Hasil pengujian pada tiap variabel dengan indikatornya menghasilkan Confirmatory Factor Analysis dengan nilai alfa 0,54-0,94 dan nilai T 6,5-109,78. Goodness of Fit measurement model memberikan hasil pada nilai square root of Average Extracted (AVE) masing-masing variabel di atas akarnya, yaitu dengan nilai 0,863 untuk variabel pengetahuan 1,000 , untuk variabel dukungan sosial 0,839 , untuk variabel sikap 0,784 , untuk motivasi 0,667 dan untuk variabel perilaku 0,648.

Berdasarkan gambar 3, hasil pengukuran nilai $\mathrm{T}$ statistik dari setiap indikator ke variabel lebih 
Faletehan Health Journal, 6 (3) (2019) 99-105 www. journal.Ippm-stikesfa.ac.id/ojs/index.php/FHJ ISSN 2088-673X | e-ISSN2597-8667

besar dari 1,96 dan 1,645 dengan tingkat kepercayaan/parameter estimasi $95 \%(\alpha=0,05)$ dan $90 \%(\alpha=0,10)$. T Hitung > T Tabel maka Ho ditolak dan $\mathrm{Ha}$ diterima, sehingga dapat disimpulkan bahwa ada pengaruh yang signifikan antara masing-masing variabel independent dan variabel dependent. Untuk persentase pengaruh langsung dan tidak langsung, disajikan pada tabel 2:

Hasil uji koefisien pada tabel 2, parameter pengetahuan menunjukan pengaruh langsung

Gambar 1: Hasil Pengukuran Outer Model Penelitian Pengaruh Langsung Dan Tidak Langsung Pengetahuan, Dukungan Sosial, Sikap, Dan Motivasi Ibu Terhadap Pemberian Susu Formula Pada Bayi Berat Badan Lahir Rendah (Model Pengukuran Outer Model dengan Aplikasi Smart PLS 3.0)

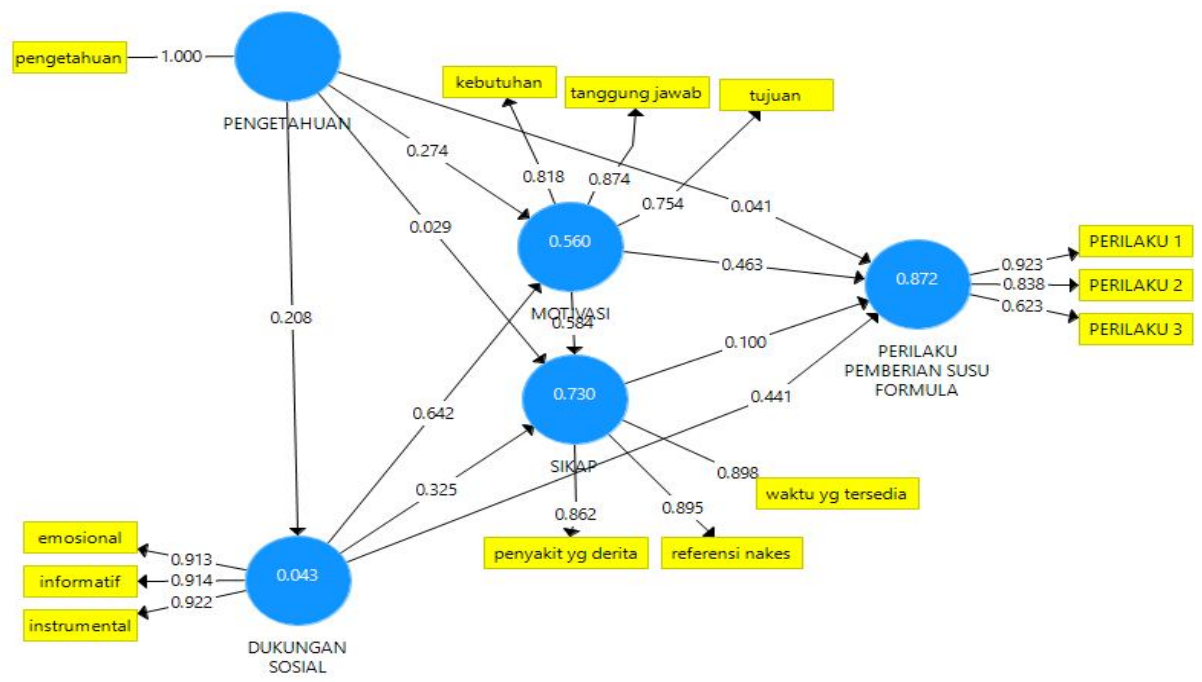

Gambar 2: Hasil Pengukuran Inner Model Awal Penelitian Pada Pengaruh Langsung Dan Tidak Langsung Pengetahuan, Dukungan Sosial, Sikap, Dan Motivasi Ibu Terhadap Pemberian Susu Formula Pada Bayi Berat Badan Lahir Rendah (Model Pengukuran Inner Model dengan Aplikasi Smart PLS 3.0)

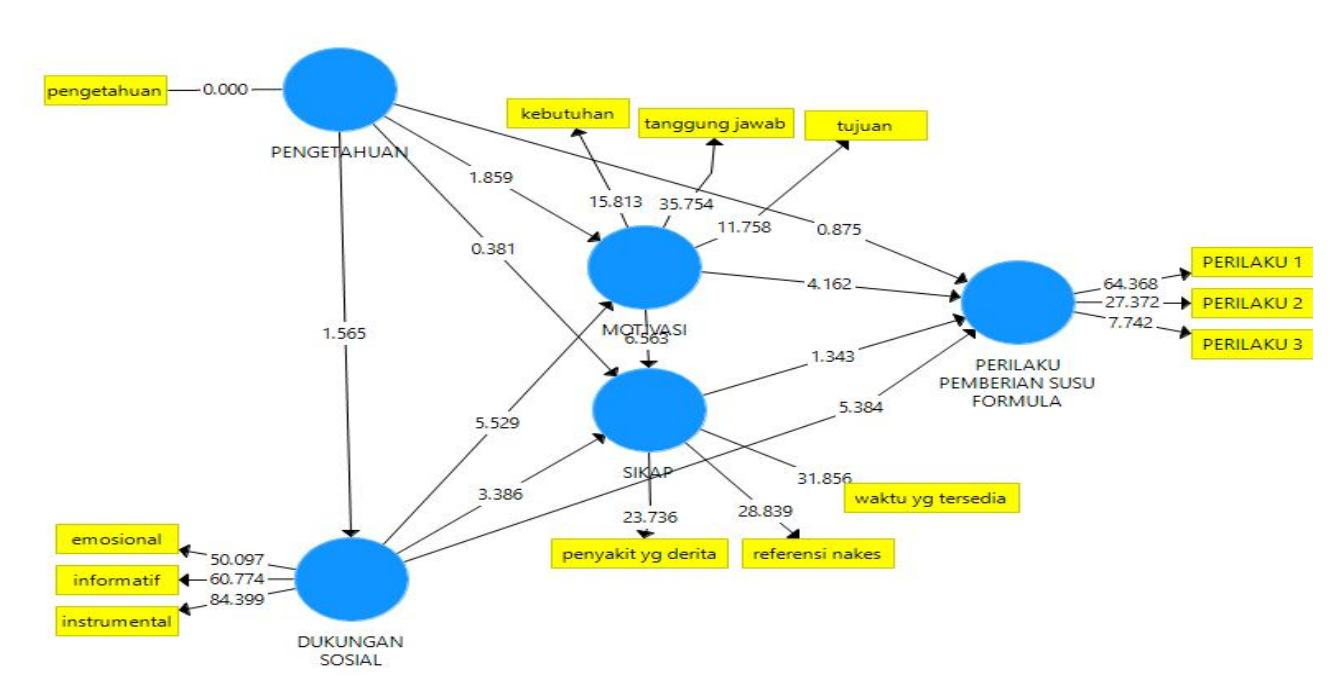

Uji yang ke dua adalah melihat signifikansi pengaruh antar konstruk sebagai hasil pengukuran sebesar $1,451 \%$ dan pengaruh tidak langsung sebesar $0,061 \%$. Motivasi berpengaruh langsung dengan nilai sebesar 40,107\% dan pengaruh tidak langsung didapat nilai sebesar 0,271. Dukungan sosial berpengaruh langsung dengan nilai sebesar $19,53 \%$, dan pengaruh tidak langsung didapat nilai $0,00 \%$ sedangkan sikap berpengaruh langsung dengan nilai $8,282 \%$ dan tidak memiliki nilai pengaruh tidak langsung. nilai $R$-Square yang juga merupakan nilai goodness-fit model. Berdasarkan pada tabel 1, 
tampak seluruh jalur memenuhi angka signifikan pada nilai $\alpha=0,05 \quad(1,96)$. Sehingga tidak dilakukan bootstrapping sebanyak sampai nilai 500 sebagai nilai maksimal responden sehingga di dapat nilai signifikansi pengaruh langsung dan tidak langsung (gambar 3).

Tabel 1. Hasil Pengukuran $R$-Square dari Variabel Pengetahuan, Dukungan Sosial, Sikap dan Motivasi Ibu

\begin{tabular}{lc}
\hline \multicolumn{1}{c}{ Variabel } & $\mathbf{R}=$ Square \\
\hline Dukungan Sosial & 0,053 \\
Motivasi & 0,560 \\
$\begin{array}{l}\text { Perilaku pemberian } \\
\text { formula }\end{array}$ & 0,872 \\
Sikap & 0,730 \\
\hline Sumber: Hasil olah data penelitian Tahun 2016
\end{tabular}

Sumber: Hasil olah data penelitian Tahun 2016

Gambar 3: Gambar Nilai T-Statistik Pada Inner Model Akhir Pada Pengaruh Langsung Dan Tidak Langsung Variabel Pengetahuan, Dukungan Sosial, Sikap, Dan Motivasi Ibu Terhadap Pemberian Susu Formula Pada Bayi Berat Badan Lahir Rendah (Model Pengukuran T-Statistik dengan Aplikasi Smart PLS 3.0)

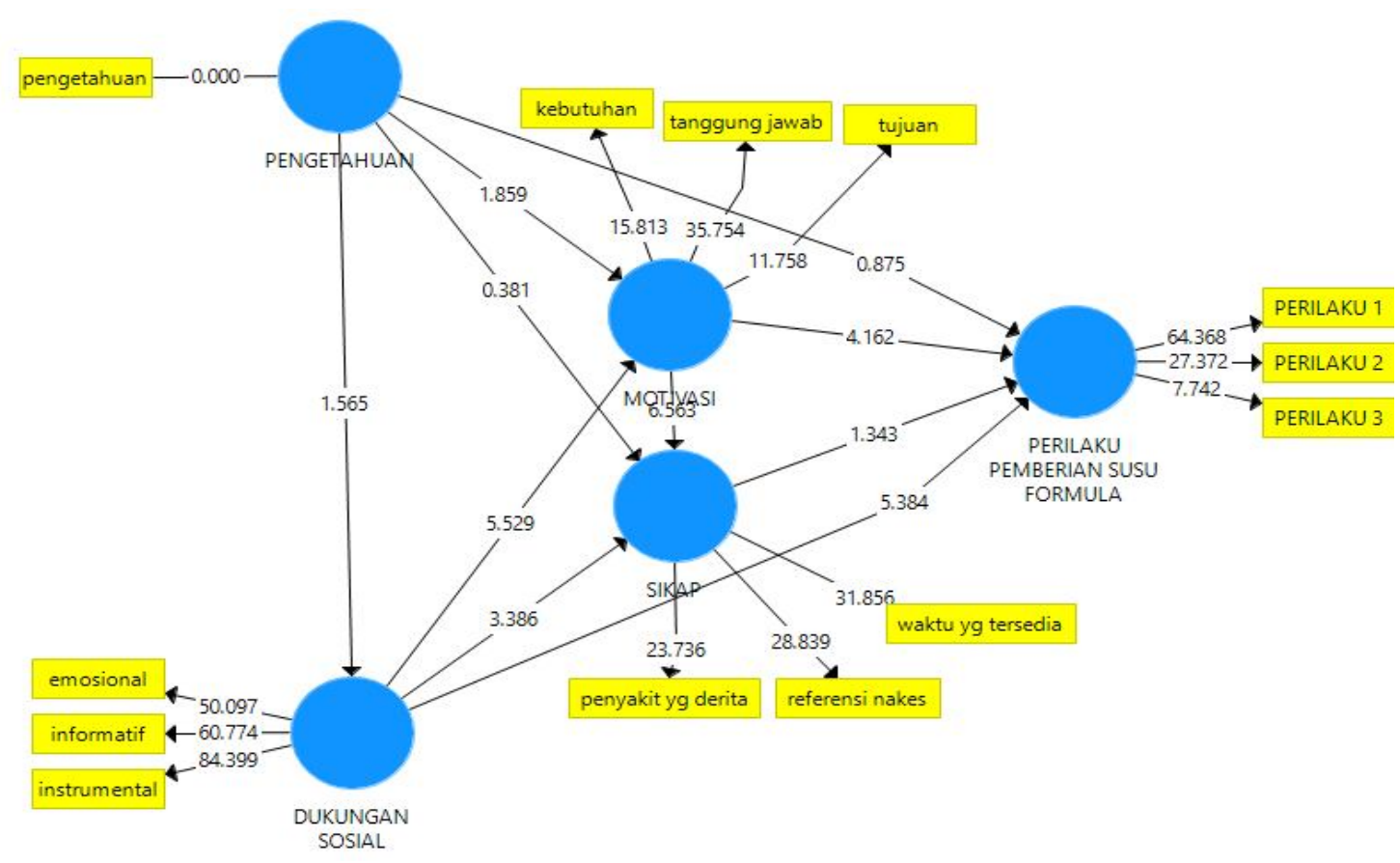

Tabel 2. Pengaruh Langsung Dan Tidak Langsung Variabel Pengetahuan, Dukungan Sosial, Sikap, dan Motivasi Ibu

\begin{tabular}{cccccccc}
\hline Variabel & $\begin{array}{c}\text { LV } \\
\text { Correlation }\end{array}$ & $\begin{array}{c}\text { Direct } \\
\text { Rho }\end{array}$ & $\begin{array}{c}\text { Indirect } \\
\text { Rho }\end{array}$ & $\begin{array}{c}\text { Total } \\
\%\end{array}$ & $\begin{array}{c}\text { Direct } \\
\%\end{array}$ & $\begin{array}{c}\text { Indirect } \\
\%\end{array}$ & $\begin{array}{c}\text { Total } \\
\%\end{array}$ \\
\hline Pengetahuan (P) & 0,354 & 0,041 & 0,596 & 0,637 & 1,451 & 0,061 & 1,5130 \\
Motivasi (M) & 0,87 & 0,461 & 0,379 & 0,840 & 40,107 & 0,271 & 40,378 \\
Sikap (S) & 0,82 & 0,101 & & 0,101 & 8,282 & & 8,282 \\
Dukungan & & & & & & & \\
Sosial (Ds) & 0,442 & 0,442 & 0,000 & 0,442 & 19,5364 & 0,000 & 19,536 \\
\hline & & & Total & 2,021 & 69,3768 & 0,333 & 69,71 \\
\hline
\end{tabular}

Sumber: Hasil olah data penelitian Tahun 2016

\section{Pengetahuan}

Kegiatan, aktivitas dan perilaku seseorang ditentukan oleh pengetahuan. Sebelum seseorang 
Faletehan Health Journal, 6 (3) (2019) 99-105

bertindak dan beraktivitas ia harus memiliki pengetahuan terlebih dahulu. Penerimaan perilaku ini didasari oleh pengetahuan, kesadaran dan perilaku positif, maka perilaku tersebut akan bersifat langgeng (long lasting), sebaliknya apabila perilaku itu tidak didasari oleh pengetahuan dan kesadaran maka tidak akan berlangsung lama (Notoatmodjo, 2010). Pada penelitian yang dilakukan didapatkan temuan bahwa ibu yang memiliki pengetahuan rendah cenderung memberikan susu formula hal ini dikarenakan kurangnya pengetahuan ibu tentang ASI eksklusif dan tidak diimbangi dengan pencarian dan pemberian informasi tentang pentingnya ASI eksklusif, berbeda dengan susu formula yang justru lebih gencar dalam melakukan promosi produknya.

Penelitian sebelumnya yang meneliti tentang pengaruh pembekalan pengetahuan pada ibu postpartum mengenai pemilihan nutrisi awal yang tepat bagi bayi BBLR menunjukkan bahwa pemberian pembekalan pengetahuan terhadap ibu postpartum dapat meminimalisir pemberian susu formula pada BBLR (Sri Ratna, 2010). Hasil penelitian ini didukung pula dengan penelitian lain yang menunjukkan bahwa kompensasi langsung maupun pengetahuan terhadap perilaku kesehatan sesuai dengan hasil analisis SEM dimana kompensasi langsung dan tidak langsung secara simultan berpengaruh signifikan terhadap perilaku kesehatan (Hadijah, 2011). Berdasarkan temuan di lapangan, pendidikan terakhir responden didominasi oleh jenjang SMP. Menurut Notoatmodjo (2010), pengetahuan yang kurang dapat dipengaruhi salah satunya oleh pendidikan. Pendidikan merupakan suatu usaha untuk mengembangkan kepribadian dan kemampuan didalam dan di luar sekolah dan berlangsung seumur hidup. Semakin banyak informasi yang masuk semakin banyak pula pengetahuan yang didapat terutama tentang pemberian susu formula pada BBLR. Selain pendidikan, ada pula pengaruh dari letak geografis/tempat tinggal yang berhubungan dengan keterjangkauan informasi yang diperoleh responden. Kecamatan Karangpawitan merupakan daerah yang sebagian besar warganya tinggal dibagian desa terpencil, sehingga untuk pengetahuan di Kecamatan Karangpawitan tidak merata dikarenakan sulit dijangkau oleh petugas kesehatan.

\section{Dukungan Sosial}

Dukungan sosial merupakan sumber emosional, informasional atau pendampingan yang diberikan oleh orang-orang disekitar individu untuk menghadapi setiap permasalahan dan krisis yang terjadi sehari-hari dalam kehidupan (Markus. E, 2010). Dari hasil penelitian, didapati hasil bahwa dukungan sosial juga mempengaruhi terhadap perilaku seseorang, dengan dukungan sosial ibu menjadi merasa dihargai dan juga didukung atas pilihan yang ibu pilih terlepas itu benar atau salah. Temuan yang didapat pada penelitian ini yakni ibu lebih memilih memberikan susu formula kepada bayinya dan didukung pula oleh keluarganya. Hal ini didukung pula oleh penelitian sebelumnya yang menyatakan bahwa dukungan sosial dan dukungan keluarga berperan penting dibandingkan dengan sikap serta berjalan seiringan dengan motivasi dari ibu sehingga ibu dapat memberikan ASI ataupun susu formula pada bayi (Deasy, 2010). Dukungan sosial dapat diperoleh dari keluarga ataupun dari selain keluarga. Ibu akan menjadikan keluarga sebagai tumpuan harapan, tempat bercerita dan tempat mengeluarkan keluh kesah bila beliau mengalami persoalan. Berdasarkan temuan dilapangan, ibu lebih memilih memberikan susu formula karena didukung pula oleh suami dan keluarga. Dukungan sosial berasal dari hubungan yang dekat dan intim. Pada umumnya menggambarkan mengenai peranaan atau pengaruh yang dapat ditimbulkan dari orang lain yang berarti seperti anggota keluarga, teman, saudara dan rekan kerja.

\section{Sikap}

Sikap merupakan keteraturan tertentu dalam hal perasaan (afeksi), pemikiran (kognisi) dan predisposisi tindakan (konasi) seseorang terhadap suatu aspek dilingkunggan sekitarnya (Saifudin Azwar, 2012). Hasil penelitian yang dilakukan bahwa sikap memiliki peranan yang tidak kalah penting dibandingkan motivasi, sikap ibu dapat mempengaruhi setiap perilaku yang akan ibu pilih mengenai pilihan untuk memberikan ASI eksklusif atau susu formula pada BBLR. Temuan pada penelitian ini yaitu sikap ibu yang lebih tertarik untuk memberikan susu formula dibandingkan ASI eksklusif dikarenakan adanya anggapan bahwa susu formula itu lebih praktis dibandingkan dengan ASI eksklusif. Hasil penelitian ini didukung pula oleh penelitian lain yang menunjukkan bahwa pemberian susu formula dapat dipengaruhi oleh sikap ibu yang kurang peduli terhadap pemberian 
susu formula yang terlalu dini (Lhaksman, 2010). Temuan pada penelitian ini yaitu sikap ibu yang lebih tertarik untuk memberikan susu formula dibandingkan ASI eksklusif dikarenakan adanya anggapan bahwa susu formula lebih praktis dibandingkan dengan ASI selain itu pula didukung oleh orang-orang yang responden anggap penting dalam kehidupannya (suami, keluarga), sehingga ibu menentukan sikap untuk memberikan susu formula pada anaknya.

\section{Motivasi}

Motivasi didefisikan dengan keadaan diri individu atau organisme yang mendorong perilaku kearah tujuan (Kartono, 2010). Berdasarkan hasil penelitian diketahui motivasi ibu memberikan susu formula pada BBLR yakni adanya tanggung jawab ibu yang berlebih pada bayinya ketika ASI ibu tidak keluar dan adanya keinginan memberikan susu formula sebagai pemenuhan nutrisi bagi bayinya karena adanya ketakutan tidak terpenuhi nutrisi apabila hanya mengandalkan ASI saja. Senada dengan penelitian yang dilakukan oleh $\mathrm{Ni}$ Wayan, menyebutkan bahwa pemberian ASI maupun susu formula oleh ibu dipengaruhi motivasi intrinsik atau yang berasal dari ibu sendiri (Ni Wayan, 2009). Didukung pula oleh penelitian lain yang menyebutkan bahwa motivasi memiliki pengaruh terhadap perilaku pemberian susu formula pada BBL (Purnajuningsih, 2010). Motivasi merupakan daya yang berasal dari dalam diri untuk menggerakkan, mendorong dan melatar belakangi seseorang dalam bertingkah laku atau bertindak. Dalam hal ini hal yang memotivasi ibu dalam memberikan susu formula pada BBLR dikarenakan tanggung jawab ibu yang berlebih sehingga menimbulkan kecemasan tersendiri pada diri ibu ditambah dengan kondisi bayi BBLR yang kesulitan dalam menghisap ASI sehingga ibu lebih memilih untuk memberikan susu formula serta kekhawatiran ibu dalam kurangnya asupan nutrisi pada BBLR bila hanya diberikan ASI. Selain itu adanya ketakutan ibu ketika bekerja tidak dapat memberikan ASI eksklusif karena pekerjaan ibu didominasi sebagai petani.

\section{Simpulan}

Simpulan dalam penelitian ini adalah motivasi memiliki pengaruh tertinggi baik pengaruh langsung maupun tidak langsung terhadap perilaku ibu dalam pemberian susu formula pada Bayi Berat Lahir Rendah (BBLR).

\section{Referensi}

Azwar, Saifudin. (2012). Sikap dalam Sehat. Jakarta : Marya Teks

Banowati, Lilis. (2016). Ilmu Gisi Dasar. Deepublish : Yogyakarta

Dinas Kesehatan. (2017). Profil Kesehatan Puskesmas Karangpawitan. Dinas Kesehatan Jawa Barat : Garut

Dinas Kesehatan. (2017). Profil Kesehatan Kabupaten Garut. Dinas Kesehatan Jawa Barat : Garut

Hasanudin. (2010). Pengetahuan dalam Dunia Kesehatan. Rhineka Cipta : Bandung

Kartono. (2010). Motivasi dalam kesehatan. Alfabeta : Bandung

Kemenkes RI. (2018). Badan Penelitian dan Pengembangan Kesehatan Kementrian Kesehatan RI. Riskesdas : Jakarta

Lhaksman. R. (2010). Pengaruh Sikap Ibu Terhadap Pemberian Susu Formula Pada BBLR di Wilayah Kerja Puskesmas Kutojoyo Bresbes. Melalui http://eresources.perpusnas.go.id:9877/docview/305 091133661/abstract/10ZXDMOPK96C16F48 FCPQ/1 ?accoountid=2061264\#center.

Pubmed.Diakses tanggal 17 November 2015 pukul 14.45 WIB

Markus. E. (2011). Peran Dukungan Sosial dan Keluarga Untuk Kesehatan. Salemba Infotek : Surabaya

Deasy. (2013). Faktor-Faktor yang Berhubungan dengan Pemberian ASI dan Susu Formula Pada BBL dan BBLR di RSUD Hartanto. Melalui http://eresources.perpusnas.go.id:2097/docview/301 143271/abstract/10ZXDMOPK96C16F48FC PQ/1 ?accoountid=2098234\#center.

Pubmed.Diakses tanggal 09 Desember 2015 pukul 18.55 WIB

Nety. R. (2010). Pengaruh Paket Cinta Ibu pada Perencanan Pulang Ibu Postpartum Terhadap, Pengetahuan, Sikap dan Perilaku Ibu dalam Merawat Bayi Prematur dan BBLR di Kota Bandung. Melalui http://eresources.perpusnas.go.id:2097/docview/305 400981/abstract/8D2OPK96C16F48FCPQ/1? accoountid=298004\#center.Pubmed.Diakses tanggal 2 Oktober 2015 pukul 13.20 WIB

Notoatmodjo. (2010). Perilaku Kesehatan. Alfabeta : Jakarta 
Faletehan Health Journal, 6 (3) (2019) 99-105 www. journal.Ippm-stikesfa.ac.id/ojs/index.php/FHJ

ISSN 2088-673X | e-ISSN2597-8667

Purnajuningsih. D. (2010). Pengaruh Pengetahuan, Sikap dan Motivasi Terhadap Perilaku Pemberian Susu Formula pada BBL Oleh Bidan Praktek Mandiri Jakarta Selatan. Melalui http://eresources.perpusnas.go.id:2997/docview/305 420981/abstract/8D2OLLMKO89O06F48FC $\mathrm{PQ} / 1$ ? accoountid=298004\#center, diunduh pada tanggal 23 September 2015 pukul 20.35 WIB

Ratna. S. (2010). Pengaruh Pembekalan Pengetahuan Pada Ibu Postpartum Mengenai Pemilihan Nutrisi Awal yang Tepat Bagi Bayi BBLR. Melalui http://eresources.perpusnas.go.id:3597/docview/305 3887761/abstract/10LOOOPK96C16F48FCP $\mathrm{Q} / 1$ ?accoountid=299804\#center.

Pubmed.Diakses tanggal 09 Oktober 2015 pukul 14.50 WIB

Sentra Laktasi. (2016). Profil Kesehatan Indonesia. Pusat Data Kesehatan : Jakarta

Siti Hadijah.H. (2011). Pengaruh Pengetahuan Terhadap Perilaku Kesehatan. Melalui http://e-

resources.perpusnas.go.id:2877/docview/870 098761/abstract/0096LLMLO6C16F48FCPQ $/ 1$ ? accoountid=299804\#center.

Pubmed.Diakses tanggal 15 Oktober 2015 pukul 14.50 WIB

Sugiyono. (2009). Metode Penelitian Kuantitatif Kualitatif dan $R \& D$. Alfabeta: Bandung

Wayan. N. (2009). Motivasi Intrinsik dan Motivasi Ekstrinsik Dalam Pemberian Air Susu Ibu (ASI) Oleh Ibu Menyusui Eksklusif dan Tidak Eksklusif. Melalui http://eresources.perpusnas.go.id:2097/docview/305 420981/abstract/8D2OPK96C16F48FCPQ/1? accoountid=298004\#center, diunduh pada tanggal 18 September 2015 pukul 15.15 WIB

Yuliarti, Nurheti. (2017). Keajaiban ASI : Makanan Terbaik Untuk Kesehatan, Kecerdasan dan Kelincahan Si Kecil. Andi Offset : Yogyakarta 